Rui Medeiros • António Morais - André Vasconcelos

Sandra Costa $\cdot$ Daniela Pinto $\cdot$ Jorge Oliveira

Carlos Lopes

\title{
The role of vitamin D receptor gene polymorphisms in the susceptibility to prostate cancer of a southern European population
}

Received: March 13, 2002 / Accepted: March 25, 2002

\begin{abstract}
Epidemiological data indicate a relationship between ultraviolet radiation, vitamin $\mathrm{D}$, and prostate cancer risk. Antiproliferative effects of vitamin D require the expression of the nuclear vitamin D receptor (VDR). A threefold increase in prostate cancer risk associated with the less active vitamin $\mathrm{D}$ receptor allele (the $\mathrm{T}$ allele from VDR TaqI polymorphism at codon 352) was reported. The role of VDR genotypes in the susceptibility to prostate cancer has not yet been studied in populations of southern Europe. In the present study, we determined VDR TaqI genotypes in Portuguese prostate cancer cases $(n=163)$ and controls $(n=211)$, a southern European population. When cases were compared with controls, we found an association of VDR $\mathrm{T}$ allele with prostate cancer risk (odds ratio [OR] = 1.87, 95\% confidence interval [CI] 1.02-3.37; $P=0.035$ ). This association was confirmed using logistic regression analysis $(\mathrm{OR}=2.11,95 \% \mathrm{CI} 1.15-3.88 ; P=0.015)$ and in particular associated to risk of prostate cancer onset in men over the age of 66 years $(\mathrm{OR}=2.36,95 \% \mathrm{CI} 1.05-5.29 ; P=$ 0.036). Fifty percent of cases older than 66 years could be attributed to the influence of this risk factor. Our results indicate that the contribution of VDR genotypes to prostate cancer susceptibility might depend on the population studied and its geographic localization, and that VDR genotypes are important in the definition of the genetic risk profile of populations of southern Europe.
\end{abstract}

Key words Prostate $\cdot$ Cancer $\cdot$ Risk $\cdot$ VDR $\cdot$ Vitamin D

\section{Introduction}

The mechanisms involved in the carcinogenesis of prostate cancer (PCa) are not well understood. Epidemiological data

R. Medeiros $(\bowtie) \cdot$ A. Morais $\cdot$ A. Vasconcelos $\cdot$ S. Costa $\cdot$ D. Pinto J. Oliveira · C. Lopes

Molecular Oncology Unit and Department of Urology, LaboratóriosPISO 4, Instituto Português de Oncologia, R. Dr. Ant. Bernardino

Almeida 4200-072 Porto, Portugal

Tel. +351-22-5502011; Fax +351-22-5026489

e-mail: mop06210@mail.telepac.pt indicate that environmental factors may account for the risk of PCa (Hanchete and Schwartz 1992; Chan et al. 1998; Ekmam 1999; Lichtenstein et al. 2000; Luscombe et al. 2001a). A relationship between ultraviolet (UV) radiation, vitamin D, and PCa risk has been suggested on the basis of some epidemiological evidence (Schwartz and Hylka 1990). A strong relationship has been reported between higher serum levels of 1,25-dihydroxyvitamin $\left.\mathrm{D}_{3}\left[1,25(\mathrm{OH}) 2 \mathrm{D}_{3}\right)\right]$, the active hormonal form of vitamin $\mathrm{D}$, and decreased risk of developing PCa (Corder et al. 1993). Furthermore, it has been demonstrated that vitamin $\mathrm{D}$ has inhibitory effects on tumor cell proliferation and prodifferentiation effects, and it influences tumor spread (Studzinski and Moore 1995; Haussler et al. 1998; McCarty et al. 2000). Antiproliferative effects of $1,25(\mathrm{OH}) 2 \mathrm{D}_{3}$ require the expression of the nuclear vitamin D receptor (VDR) (Hedlund et al. 1996a).

The gene encoding VDR has two sets of polymorphisms, one at the $3^{\prime}$ end of the gene involving a series of polymorphic sites (Morrison et al. 1994), and the other at the $5^{\prime}$ end of the gene affecting the start codon (Gross et al. 1996). Certain alleles of the $V D R$ gene are associated with increased VDR activity and higher serum vitamin D levels (Morrison et al. 1994). Epidemiological studies trying to find an association between VDR polymorphisms and the genetic susceptibility to PCa show controversial results (Taylor et al. 1996; Kibel et al. 1998; Correa-Cerro et al. 1999; Watanabe et al. 1999; Blazer et al. 2000; Bousema et al. 2000; Habuchi et al. 2000; Chokkalingam et al. 2001; Luscombe et al. 2001b). This may be due to the complexity of mechanisms that influence the vitamin $\mathrm{D}$ pathway. The contribution of vitamin D to the risk of PCa may depend on the population studied, as well as on several environmental and diet factors that influence that population. Therefore, we hypothesize that each population has to evaluate its own genetic profile of cancer risk; that may help us to understand the geographic and racial differences reported for PCa incidence and mortality.

The world's highest incidence rates are found in the United States and Scandinavian countries and the lowest incidence rates are found in China and Japan. (Parkin 1998). Black Americans have a marked increased risk of 
developing PCa (Morton 1994) and have the highest incidence rates. In European countries, the PCa incidence rates are very high in northern and western Europe, and lower in southern Europe (Parkin 1998; Ferlay et al. 1999; Levi et al. 2000). Populations of southern Europe are usually of darker complexion, are exposed to higher levels of sun irradiation, and have different diets (compared with northern Europe populations).

Taylor et al. (1996) found a three-fold increase in prostate cancer risk associated with the less active vitamin D allele (the $\mathrm{T}$ allele from VDR TaqI polymorphism at codon 352) in a Caucasian American population. The role of VDR genotypes in the susceptibility to prostate cancer has not yet been studied in populations of southern Europe. Considering that prostate cancer is a complex, multifactorial disease with genetic and environmental factors involved in its etiology and that the influence of some factors may differ according to race and geographic localization, we determined VDR TaqI genotypes in Portuguese prostate cancer cases and controls, thereby focusing on a southern European population.

\section{Subjects and methods}

\section{Study population}

Consecutive patients $(n=163)$ with histologically verified PCa were enrolled in our study between January 1998 and December 1999 with the Department of Urology in the Portuguese Institute of Oncology in Porto, Portugal.

All patients were at time of diagnosis. The age at diagnosis ranged from 45 to 86 years, with a median age of 66 years. Clinical characteristics, including Gleason grade (Gleason 1990), prostate-specific antigen (PSA), tumor stage, and age at diagnosis were obtained from medical records. Seventy-three $(58.4 \%)$ cases had localized prostate disease, and 52 (41.6\%) had advanced disease (T3/T4: defined as a tumor invading and extending beyond the prostate capsule and/or extending into adjacent tissue or involving regional lymph nodes or distant metastatic sites). All samples were obtained with the informed consent of the participants before their inclusion in the study. The control group consisted of 211 healthy individuals with no evidence of neoplastic disease and age matched for the same age interval as the PCa group. This control group (median: 64 years; range: 41 to 84 years) was recruited from the Institute's blood donors' bank, or from cancer-free male attendants with normal levels of serum PSA at routine clinical checkup. All participants were Caucasians living in the Porto district. Approximately $8 \mathrm{ml}$ of venous blood were obtained with a standard venipuncture technique using ethylenediaminetetracetate-containing tubes. DNA was extracted from the white blood cell fraction from each study subject using a salting-out protocol (Miller et al. 1988).

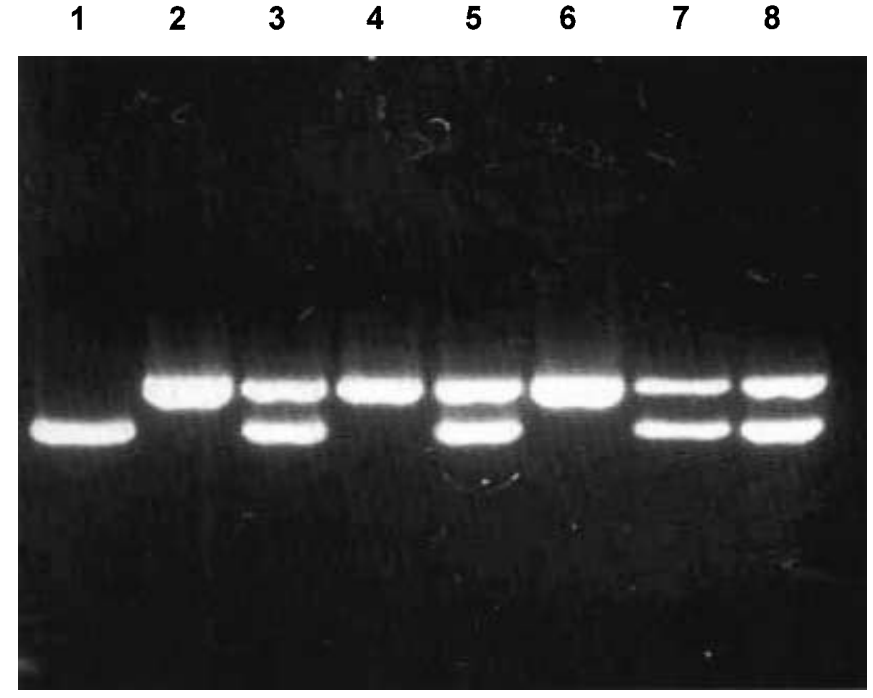

Fig. 1. Detection of vitamin $D$ receptor gene polymorphisms, from genornic DNA. After amplification, polymerase chain reaction products were digested with the restriction enzyme Taq I, and the Taq I wild-type $(\mathrm{T})$ and variant $(\mathrm{t})$ alleles were detected after electrophoresis in agarosis gel. The $\mathrm{T}$ allele was refractory to digestion (345 bp), whereas fragments of $260 \mathrm{bp}$ and $85 \mathrm{bp}$ identified the $\mathrm{t}$ allele: genotypes tt (lane 1), Tt (lanes 3, 5, 7, and 8), and TT (lanes 2, 4, and 6)

Genotyping of VDR TaqI polymorphism by polymerase chain reaction-restriction fragment length polymorphism (PCR-RFLP)

VDR TaqI genotype was determined by a PCR-based methodology as previously described (Hutchinson et al. 2000). The polymorphic site was amplified by use of a forward primer (5'-CAG AGC ATG GAC AGG GAG CAA G-3') and a reverse primer (5'-CGG CAG CGG ATG TAC GTC TGC AG-3'). The cycling conditions were $94^{\circ} \mathrm{C}$ for $5 \mathrm{~min}$, followed by 35 cycles at $94^{\circ} \mathrm{C}$ for $1 \mathrm{~min}, 60^{\circ} \mathrm{C}$ for $1 \mathrm{~min}$, and $72^{\circ} \mathrm{C}$ for $40 \mathrm{~s}$, with a final cycle at $72^{\circ} \mathrm{C}$ for $10 \mathrm{~min}$. A $10-\mu$ l aliquot was digested with 1.5 units of $\mathrm{Taq}$ I restriction enzyme at $65^{\circ} \mathrm{C}$ for $20 \mathrm{~h}$ and then separated on a $1.5 \%$ agarose gel (Fig. 1). The three possible genotypes were defined by three distinct banding patterns: TT $(345 \mathrm{bp}), \mathrm{Tt}$ (345 bp, 260 bp), and tt (260 bp).

\section{Statistical analysis}

Analysis of data was performed using the computer software SPSS for Windows (Version 7.5) and Epi Info (Version 6.04a). Chi-square analysis was used to compare categorical variables. A $5 \%$ level of significance was used in the analysis. The observed number of each genotype was compared with that expected for a population in the HardyWeinberg equilibrium using a $\chi^{2}$ test. For statistical analysis we rejected one case because it was not Caucasian and six controls because their age was under 45 years. We stratified the analysis according to Gleason grade, disease status, age at diagnosis (median age: 66 years), and risk of disease progression, whereby high risk was defined as either high 
Table 1. Distribution of VDR genotypes among cases and controls

\begin{tabular}{|c|c|c|c|c|c|}
\hline & \multicolumn{3}{|c|}{ VDR TaqI genotype (\%) } & \multirow{2}{*}{$\frac{\mathrm{OR}}{\mathrm{TT} / \mathrm{Tt} \text { vs tt }}$} & \multirow{2}{*}{$\frac{\text { Adjusted } \mathrm{OR}^{\mathrm{a}}}{\mathrm{TT} / \mathrm{Tt} \text { vs } \mathrm{tt}}$} \\
\hline & $\mathrm{TT}$ & $\mathrm{Tt}$ & $\mathrm{tt}$ & & \\
\hline \multicolumn{6}{|l|}{ All } \\
\hline Controls $(n=206)$ & $73(35.4)$ & $92(44.7)$ & $41(19.9)$ & \multirow{2}{*}{$\begin{array}{l}\mathrm{OR}=1.87 ; P=0.035 \\
(95 \% \mathrm{CI}, 1.02-3.37)\end{array}$} & \multirow{2}{*}{$\begin{array}{l}\mathrm{OR}=2.11 ; P=0.015 \\
(95 \% \text { CI, } 1.15-3.88)\end{array}$} \\
\hline Cases $(n=162)$ & $52(32.1)$ & $91(56.2)$ & $19(11.7)$ & & \\
\hline \multicolumn{6}{|l|}{ Age $<66$ years } \\
\hline Controls $(n=125)$ & $48(38.4)$ & $57(45.6)$ & $20(16.0)$ & \multirow{2}{*}{$\begin{array}{l}\mathrm{OR}=1.64 ; P=0.262 \\
(95 \% \mathrm{CI}, 0.68-3.93)\end{array}$} & \multirow{2}{*}{$\begin{array}{l}\mathrm{OR}=2.12 ; P=0.117 \\
(95 \% \mathrm{CI}, 0.82-5.47)\end{array}$} \\
\hline Cases $(n=77)$ & $30(39.0)$ & $39(50.6)$ & $8(10.4)$ & & \\
\hline \multicolumn{6}{|l|}{ Age $\geq 66$ years } \\
\hline Controls $(n=81)$ & $25(30.9)$ & $35(43.2)$ & $21(25.9)$ & \multirow{2}{*}{$\begin{array}{l}\mathrm{OR}=2.35 ; P=0.034 \\
(95 \% \mathrm{CI}, 1.05-5.27)\end{array}$} & \multirow{2}{*}{$\begin{array}{l}\mathrm{OR}=2.36 ; P=0.036 \\
(95 \% \mathrm{CI}, 1.05-5.29)\end{array}$} \\
\hline Cases $(n=85)$ & $22(25.9)$ & $52(61.2)$ & $11(12.9)$ & & \\
\hline
\end{tabular}

VDR, Vitamin D receptor; CI, confidence interval

${ }^{a}$ Adjusted odds ratio (OR) for age (logistic regression analysis)

grade (Gleason $\geq 7$ ) or advanced clinical stage (T3 and T4) and low-risk cases were defined as both low grade and early stage. This type of stratified analysis has been suggested before (Pisansky et al. 1997; George et al. 2001). The odds ratio (OR) and its $95 \%$ confidence interval (CI) was calculated as a measure of the association between VDR genotypes and prostate cancer risk. Multivariate logistic regression analysis was used to calculate the adjusted OR and $95 \% \mathrm{CI}$ for the influence of VDR genotypes in the risk of prostate cancer, with adjustment for age.

We calculated the attributable proportion (AP), according to that previously reported by Schiffman et al. (1993), using the following formula: $A P=P R F \times(1-1 / a O R)$. The attributable proportion (AP) is the fraction of disease attributable to the risk factor, PRF is the percentage of the risk factor in case subjects, and aOR is the adjusted odds ratio.

\section{Results}

The distribution of VDR TaqI genotypes among cases and controls and risk of cancer of the prostate because of the VDR polymorphism are shown in Table 1 . The frequency of TT, Tt, and tt genotypes was $35.4 \%, 44.7 \%$, and $19.9 \%$ in normal controls and $32.1 \%, 56.2 \%$, and $11.7 \%$ in PCa cases, respectively. The observed genotype distributions in the groups did not differ from those that would be expected from the Hardy-Weinberg equilibrium $(P=0.282$ for cases and $P=0.394$ for controls). We observed that the T allele (genotypes $\mathrm{TT}$ and $\mathrm{Tt}$ ) was overrepresented in PCa patients (OR $=1.87,95 \%$ CI 1.02-3.37; $P=0.035)$. When we stratified the analysis further according to median age (men older than 66 years vs men younger than 66 years), we observed that, for the group of men older than 66 years carrying a T-allele genotype, there is a statistically significant increase of PCa risk (OR $=2.35,95 \%$ CI $1.05-$ 5.27; $P=0.034)$. Multivariate logistic regression analysis confirmed this association of T-allele VDR genotypes with PCa risk $(\mathrm{OR}=2.11,95 \% \mathrm{CI} 1.15-3.88 ; P=0.015)$ and, in particular, the association with the onset of $\mathrm{PCa}$ in men
Table 2. Multivariate analysis for the presence of the $\mathrm{T}$ allele and the risk for prostate cancer, prostate cancer onset after the age of 66 years, aggressive tumor (Gleason $\geq 7$ ), advanced disease (T3/T4), and progression of the disease

\begin{tabular}{llll}
\hline Increased risk for & $\mathrm{aOR}^{\mathrm{a}}$ & $95 \% \mathrm{CI}$ & $P$ \\
\hline Cancer & 2.11 & $1.15-3.88$ & 0.015 \\
Cancer onset after the & 2.36 & $1.05-5.29$ & 0.036 \\
$\quad$ age of 66 years & 1.55 & $0.72-3.35$ & 0.260 \\
Gleason $\geq 7$ & 1.36 & $0.64-2.90$ & 0.411 \\
Advanced disease & 1.30 & $0.67-2.53$ & 0.429 \\
Progression of the disease &
\end{tabular}

${ }^{a}$ Adjusted odds ratio (aOR) for age (logistic regression analysis)

older than 66 years $(\mathrm{OR}=2.36,95 \%$ CI $1.05-5.29 ; P=$ $0.036)$. No statistical significance was observed regarding the association of VDR Taq1 genotypes and tumor grade (Gleason $<7$ vs Gleason $=7, P=0.260$ ), disease status (advanced vs localized, $P=0.411$ ), and the risk of disease progression (high risk vs low risk, $P=0.429$ ), as shown in Table 2.

The comparison of our results for VDR genotype frequencies with reported frequencies for other populations is shown in Table 3. For the entire case group, the proportion of PCa cases attributable (attributable proportion) to the Tallele genotypes was $44.0 \%$. Morever, for patients older than 66 years, $50.2 \%$ of all cases could be attributed to the influence of this risk factor.

\section{Discussion}

Environmental, geographical, and racial factors have been demonstrated to be important in prostate cancer risk. The geographical distribution of prostate cancer mortality in the United States has been interpreted as supporting the hypothesis that low levels of vitamin $\mathrm{D}$ are related to sunlight exposure and may increase cancer risk (Hanchete and Schwartz 1992). This idea is further supported by analysis of vitamin D metabolites in sera stored before diagnosis for prostate cancer cases and controls (Corder et al. 1993; 
Table 3. Reported VDR TaqI RFLP genotype frequencies in normal control subjects from different ethnic populations

\begin{tabular}{|c|c|c|c|c|c|c|}
\hline \multirow[b]{2}{*}{ Study group } & \multirow[b]{2}{*}{ Total } & \multicolumn{3}{|c|}{ VDR TaqI RFLP } & \multirow[b]{2}{*}{$P^{*}$} & \multirow[b]{2}{*}{ Reference } \\
\hline & & $\begin{array}{l}\text { TT } \\
n(\%)\end{array}$ & $\begin{array}{l}\mathrm{Tt} \\
n(\%)\end{array}$ & $\begin{array}{l}\mathrm{tt} \\
n(\%)\end{array}$ & & \\
\hline Caucasian American & 162 & $53(33.0)$ & $73(45.0)$ & $36(22)$ & 0.755 & Taylor et al. 1996 \\
\hline Caucasian American & 41 & $15(36.5)$ & $18(43.9)$ & $8(19.5)$ & 0.998 & Kibel et al. 1998 \\
\hline Japanese & 202 & $160(79.2)$ & $36(17.8)$ & $6(3.0)$ & $<0.001$ & Watanabe et al. 1999 \\
\hline Japanese & 128 & $96(75.0)$ & $30(23.4)$ & $2(1.6)$ & $<0.001$ & Habuchi et al. 2000 \\
\hline Caucasian European (UK) & 93 & $39(41.9)$ & $41(44.1)$ & $13(14.0)$ & 0.407 & Hutchinson et al. 2000 \\
\hline Caucasian European (UK) & 154 & $57(37.0)$ & $67(43.5)$ & $30(19.5)$ & 0.951 & Luscombe et al. 2001 \\
\hline Caucasian European (Portugal) & 211 & $75(35.5)$ & $95(45.0)$ & $41(19.5)$ & referent & Present study 2002 \\
\hline
\end{tabular}

VDR, Vitamin D receptor; RFLP, restriction fragment length polymorphism

* Chi square analysis comparing reported genotype frequencies with the present study

Ahonen et al. 2000) and by the analysis of the expression patterns of vitamin D in human prostate (Krill et al. 2001). It has also been shown that the antiproliferative effects of $1,25(\mathrm{OH}) 2 \mathrm{D}_{3}$ require the expression of the nuclear VDR (Hedlund et al. 1996a). 1,25(OH)2 $\mathrm{D}_{3}$ is capable of acting through both nongenomic signalling pathways involving a membrane-associated receptor and genomic pathways involving the nuclear VDR (Hedlund et al. 1996b). The most active vitamin $\mathrm{D}$ metabolite, 1 alpha, 25-dihydroxyvitamin $\mathrm{D}_{3}\left[1,25(\mathrm{OH}) 2 \mathrm{D}_{3}\right]$, was also shown to increase the expression of PSA, a differentiation marker, in prostate cells (Miller et al. 1992; Skowronski et al. 1993).

The VDR belongs to the steroid and thyroid hormone receptor family of ligand-activated transcription factors (Tuohimaa et al. 2001). Nuclear receptor superfamily comprise a large group of transcription factors, the functions of which, in many cases, are regulated by small, lipophilic hormonal ligands that include steroids, retinoids, vitamin D, and thyroid hormone. The gene encoding VDR is located on chromosome 12cen-q12 (Taymans et al. 1999), contains 14 exons, and spans $\sim 75 \mathrm{~kb}$ of genomic DNA (Miyamoto et al. 1997; Crofts et al. 1998). The VDR gene has two sets of polymorphisms, one at the $3^{\prime}$ end of the gene involving a series of polymorphic sites (Morrison et al. 1994) and the other at the $5^{\prime}$ end of the gene affecting the start codon (Gross et al. 1996). The 3' polymorphisms are defined by the enzymes BsmI, ApaI, and TaqI, and a poly-A microsatellite, all of which are in linkage disequilibrium (Peehl 1999). Although neither the TaqI RFLP in exon 9 nor the linked BsmI and ApaI RFLPs in intron 8 are known to have functional consequences themselves, these sequence polymorphisms have been shown to be associated with varying levels of the circulating VDR ligand 1,25-D (Morrison 1994). Significant higher serum levels of $1,25(\mathrm{OH}) 2 \mathrm{D}_{3}$ have been reported in people who are homozygous for the $t$ allele relative to those who are heterozygous or homozygous for the T allele (Morrison et al. 1994). Taylor et al. (1996) found a three-fold increase in prostate cancer risk associated with the less active vitamin $\mathrm{D}$ allele (the $\mathrm{T}$ allele from the VDR TaqI polymorphism at codon 352) and Ingles et al. (1997) found a relative risk of 4.6 of developing prostate cancer for carriers of the L VDR poly-A allele. However, controversial results have been reported about the role of VDR polymorphisms in prostate cancer suscep- tibility in different populations (Kibel et al. 1998; CorreaCerro et al. 1999; Watanabe et al. 1999; Blazer et al. 2000; Bousema et al. 2000; Habuchi et al. 2000; Chokkalingam et al. 2001; Luscombe et al. 2001; Schatzl et al. 2001).

The worldwide incidence of clinical PCa shows strong age, race, and geographical dependence, being diagnosed in older men and African Americans being at high risk and Asians being at low risk. Interestingly, the photoconversion of 7-dehydrocholesterol to $1,25(\mathrm{OH}) 2 \mathrm{D}_{3}$ is inversely proportional to the degree of skin pigmentation (Clemens et al. 1982). In Europe, a north-south difference is evidenced by annual incidence rates, with the highest incidence in Scandinavian countries. For instance, the age-standardized incidence for Finland and Sweden (68.46 and 63.58 per 100000 , respectively) is three-fold higher than it is in Italy, Spain, and Greece $(23.55,22.50$, and 18.91 per 100000 , respectively) and almost two-fold higher when compared with Portugal (34.70 per 100000) (Ferlay et al. 1999).

Our results are in agreement with the hypothesis that VDR genotypes may have a role in PCa risk for some populations and this risk may be influenced by several intrinsic and extrinsic factors that are characteristic of each population in each geographic localization. Results from our study also show that the influence of the $\mathrm{T}$ allele of VDR genotypes in cancer susceptibility is more important for older patients. This influence is consistent with the information that the elderly are frequently vitamin D-deficient because of less exposure to UV radiation and a decline in the ability to synthesize $1,25(\mathrm{OH}) 2 \mathrm{D}_{3}$ with age (Peehl 1999). Therefore, carriers of the $T$ allele who already have lower blood circulation of vitamin D might be at a higher risk of developing PCa.

When we compared our results with the reported VDR genotype frequencies in normal control subjects (Table 3) from different populations, we observed that our population has a similar pattern to other European or American Caucasian populations. Interestingly, the frequency of our risk of $\mathrm{T}$ allele is higher for the Japanese populations when compared with our control population $(P<0.001)$. A possible explanation for this intriguing conclusion may be that different genetic risk factors for the Japanese population must be taken into account and that Japanese men are considered to be much less influenced by environmental risk factors for PCa (Oishi et al. 1995; Habuchi et al. 2000). 
Furthermore, diet has also been proposed as a risk factor to $\mathrm{PCa}$, and the low risk for indigenous Japanese people has been related to traditional diet. This diet, among other attributes, is rich in oily fish, which are an important dietary source of vitamin D (Peehl 1999). Therefore, this factor would neutralize the relevance of VDR genotypes on the determination of genetic risk of PCa.

Importantly, cancer susceptibility is associated with an interaction between host predisposition and exposure. We hypothesized that the contribution of VDR genotypes in prostate cancer susceptibility may depend upon the population studied and its geographic localization.

Acknowledgments The authors would like to thank to Liga Portuguesa Contra o Cancro-Centro Regional do Norte (Portuguese League Against Cancer), for their support. Rui Medeiros is the short name of Rui Manuel de Medeiros Melo Silva. We acknowledge Drs Carlos Torres and Isabel Torres for their helpful assistance in the management of normal controls. We gratefully acknowledge funding of this work by the Minister of Health of Portugal (CFICS-255/99).

\section{References}

Ahonen MH, Tenkanen L, Teppo L, Hakama M, Tuohimaa P (2000) Prostate cancer risk and prediagnostic serum 25-hydroxyvitamin D levels (Finland). Cancer Causes Control 11:847-852

Blazer DG, Umbach DM, Bostick RM, Taylor JA (2000) Vitamin D receptor polymorphisms and prostate cancer. Mol Carcinog 27:18-21

Bousema JT, Bussemakers MJ, van Houwelingen KP, Debruyne FM, Verbeek AL, de La Rosette JJ, Kiemeney LA (2000) Polymorphisms in the vitamin D receptor gene and the androgen receptor gene and the risk of benign prostatic hyperplasia. Eur Urol 37:234238

Chan MJ, Stampfer MJ, Giovannuci EL (1998) What causes prostate cancer? A brief summary of the epidemiology. Semin Cancer Biol 8:263-273

Chokkalingam AP, McGlynn KA, Gao YT, Pollak M, Deng J, Sesterhenn IA, Mostofi FK, Fraumeni JF Jr, Hsing AW (2001) Vitamin $\mathrm{D}$ receptor gene polymorphisms, insulin-like growth factors, and prostate cancer risk: a population-based case-control study in China. Cancer Res 61:4333-4336

Clemens TL, Adams JS, Henderson SL, Holick MF (1982) Increased skin pigment reduces the capacity of the skin to synthesize vitamin $\mathrm{D}_{3}$. Lancet 1:74-76

Corder EH, Guess HA, Hulka BS, Friedman GD, Sadler M, Vollmer RT, Lobaugh B, Drezner MK, Vogelman JH, Orentreich N (1993) Vitamin D and prostate cancer: a prediagnostic study with stored sera. Cancer Epidemiol Biomarkers Prev 2:467-472

Correa-Cerro L, Berthon P, Haussler J, Bochum S, Drelon E, Mangin P, Fournier G, Paiss T, Cussenot O, Vogel W (1999) Vitamin D receptor polymorphisms as markers in prostate cancer. Hum Genet 105:281-287

Crofts LA, Hancock MS, Morrison NA, Eisman JA (1998) Multiple promoters direct the tissue-specific expression of novel $\mathrm{N}$-terminal variant human vitamin D receptor gene transcripts. Proc Natl Acad Sci USA 95:10529-10534

Ekmam P (1999) Genetic and environmental factors in prostate cancer genesis: identifying high-risk cohorts. Eur Urol 35:362-369

Ferlay J, Bray F, Sankila R, Parkin DM (1999) EUCAN: cancer incidence, mortality and prevalence in the European Union 1996, version 3.1. IARC Cancer Base No. 4. IARC, Lyon. Limited version available from URL: http://www-dep.iarc.fr/eucan/eucan.htm

George D, Shepard T, Ma J, Giovannuci, Kantoff P, Stampfer M (2001) PTEN polymorphism (IVS4) is not associated with risk of prostate cancer. Cancer Epidemiol Biomarkers Prev 10:411-412

Gleason DF (1990) Histological grading of prostatic carcinoma. In: Bostwick DG (ed) Pathology of the prostate. Churchill Livingstone, New York, pp 83-93
Gross C, Eccleshall TR, Malloy PJ, Villa ML, Marcus R, Feldman D (1996) The presence of a polymorphism at the translation initiation site of the vitamin D receptor gene is associated with low bone mineral density in postmenopausal Mexican-American women. J Bone Miner Res 11:1850-1855

Habuchi T, Suzuki T, Sasaki R, Wang L, Sato K, Satoh S, Akao T, Tsuchiya N, Shimoda N, Wada Y, Koizumi A, Chihara J, Ogawa O, Kato T (2000) Association of vitamin D receptor gene polymorphism with prostate cancer and benign prostatic hyperplasia in a Japanese population. Cancer Res 60:305-308

Hanchete CL, Schwartz GG (1992) Geographic patterns of prostate cancer mortality: evidence for a protective effect of ultraviolet radiation. Cancer 70:2861-2861

Haussler MR, Whitfield GK, Haussler CA, Hsieh JC, Thompson PD, Selznick SH, Dominguez CE, Jurutka PW (1998) The nuclear vitamin $\mathrm{D}$ receptor: biological and molecular regulatory properties revealed. J Bone Miner Res 13:325-349

Hedlund TE, Moffatt KA, Miller GJ (1996a) Stable expression of the nuclear vitamin $\mathrm{D}$ receptor in the human prostatic carcinoma cell line JCA-1: evidence that the antiproliferative effects of 1 alpha, 25dihydroxyvitamin $D_{3}$ are mediated exclusively through the genomic signaling pathway. Endocrinology 137:1554-1561

Hedlund TE, Moffatt KA, Miller GJ (1996b) Vitamin D receptor expression is required for growth modulation by 1 alpha, 25dihydroxyvitamin $\mathrm{D}_{3}$ in the human prostatic carcinoma cell line ALVA-31. J Steroid Biochem Mol Biol 58:277-288

Hutchinson P, Osborne J, Lear J, Smith A, Bowers P, Morris P, Jones P, York C, Strange R, Fryer A (2000) Vitamin D receptor polymorphisms are associated with altered prognosis in patients with malignant melanoma. Clin Cancer Res 6:498-504

Ingles SA, Ross RK, Yu MC, Irvine RA, La Pera G, Haile RW, Coetzee GA (1997) Association of prostate cancer risk with genetic polymorphisms in vitamin D receptor and androgen receptor. J Natl Cancer Inst 89:166-170

Kibel AS, Isaacs SD, Isaacs WB, Bova GS (1998) Vitamin D receptor polymorphisms and lethal prostate cancer. J Urol 160:1405-1409

Krill D, DeFlavia P, Dhir R, Luo J, Becich MJ, Lehman E, Getzenberg RH (2001) Expression patterns of vitamin D receptor in human prostate. J Cell Biochem 82:566-572

Levi F, La Vecchia L, Boyle P (2000) The rise and fall of prostate cancer. Eur J Cancer Prev 9:381-385

Lichtenstein P, Holm N, Verkasalo P, Iliadou A, Kaprio J, Koskenvuo M, Pukkala E, Skytthe A, Hemminki K (2000) Environmental and heritable factors in the causation of cancer. N Engl J Med 343:78-85

Luscombe CJ, Fryer A, French M, Liu S, Saxby M, Jones P, Strange R (2001a) Exposure to ultraviolet radiation: association with susceptibility and age at presentation with prostate cancer. Lancet 358:641642

Luscombe CJ, French ME, Liu S, Saxby MF, Jones PW, Fryer AA, Strange RC (2001b) Prostate cancer risk: associations with ultraviolet radiation, tyrosinase and melanocortin-1 receptor genotypes. Br J Cancer 85:1504-1509

McCarty MF (2000) Parathyroid hormone may be a cancer promoter - an explanation for the decrease in cancer risk associated with ultraviolet light, calcium and vitamin D. Med Hypotheses 54:475-482

Miller AS, Dykes DD, Polesky HF (1988) A simple salting out procedure for extracting DNA from human nucleated cells. Nucleic Acids Res 16:1215

Miller GJ, Stapleton GE, Ferrara JA, Lucia MS, Pfister S, Hedlund TE, Upadhya P (1992) The human prostatic carcinoma cell line LNCaP expresses biologically active, specific receptors for 1 alpha, 25dihydroxyvitamin $\mathrm{D}_{3}$. Cancer Res 52:515-520

Miyamoto K, Kesterson RA, Yamamoto H, Taketani Y, Nishiwaki E, Tatsumi S, Inoue Y, Morita K, Takeda E, Pike JW (1997) Structural organization of the human vitamin D receptor chromosomal gene and its promoter. Mol Endocrinol 11:1165-1179

Morrison NA, Qi JC, Tokita A, Kelly PJ, Crofts L, Nguyen TV, Sambrook PN, Eisman JA (1994) Prediction of bone density from vitamin D receptor alleles. Nature 367:284-287

Morton RA (1994) Racial differences in adenocarcinoma of the prostate in North American men. Urology 44:637-638

Oishi K, Yoshida O, Schroeder FH (1995) The geography of prostate cancer and its treatment in Japan. Cancer Surv 23:267-280

Parkin DM (1998) The global burden of cancer. Semin Cancer Biol 8:219-235 
Peehl DM (1999) Vitamin D and prostate cancer risk. Eur Urol 35:392394

Pisansky TM, Kahn M, Rasp G, Cha S, Haddock M, Bostwick D (1997) A multiple prognostic index predictive of disease outcome after irradiation for clinically localized prostate cancer. Cancer 79:337-344

Schatzl G, Gsur A, Bernhofer G, Haidinger G, Hinteregger S, Vutuc C, Haitel A, Micksche M, Marberger M, Madersbacher S (2001) Association of vitamin $\mathrm{D}$ receptor and 17 hydroxylase gene polymorphisms with benign prostatic hyperplasia and benign prostatic enlargement. Urology 57:567-572

Schiffman M, Bauer H, Hoover R, Glass A, Cadell D, Rush B, Scott D, Sherman M, Kurman R, Wacholder S, Stanton C, Manos M (1993) Epidemiologic evidence showing that human papillomavirus infection causes most cervical intraepithelial neoplasia. J Natl Cancer Inst 85:958-964

Schwartz GG, Hylka BS (1990) Is vitamin D deficiency a risk factor for prostate cancer? (Hypothesis) Anticancer Res 10:1307

Skowronski RJ, Peehl DM, Feldman D (1993) Vitamin D and prostate cancer: 1,25 dihydroxyvitamin $D_{3}$ receptors and actions in human prostate cancer cell lines. Endocrinology 132:1952-1960
Studzinski G, Moore D (1995) Sunlight - can it prevent as well as cause cancer? Cancer Res 55:4014-4022

Taylor JA, Hirvonen A, Watson M, Pittman G, Mohler JL, Bell DA (1996) Association of prostate cancer with vitamin D receptor gene polymorphism. Cancer Res 56:4108-4110

Taymans SE, Pack S, Pak E, Orban Z, Barsony J, Zhuang Z, Stratakis CA (1999) The human vitamin D receptor gene (VDR) is localized to region 12 cen-q12 by fluorescent in situ hybridization and radiation hybrid mapping: genetic and physical VDR map. J Bone Miner Res 14:1163-1166

Tuohimaa P, Lyakhovich A, Aksenov N, Pennanen P, Syvala H, Lou YR, Ahonen M, Hasan T, Pasanen P, Blauer M, Manninen T, Miettinen S, Vilja, Ylikomi T (2001) Vitamin D and prostate cancer. J Steroid Biochem Mol Biol 76:125-134

Watanabe M, Fukutome K, Murata M, Uemura H, Kubota Y, Kawamura J, Yatani R (1999) Significance of vitamin D receptor gene polymorphism for prostate cancer risk in Japanese. Anticancer Res 19:4511-4514

Zagars G, Eschenbach A, Ayala A (1993) Prognostic factors in prostate cancer. Cancer 72:1709-1725 